\title{
Clinical Value of Plasma Creatine Kinase and Uric Acid Levels during First Week of Life
}

\author{
B. A. WHARTON, * URMILLA BASSI, G. GOUGH, and ANGELA WILLIAMS \\ From the Department of Child Health, University of Bristol
}

\begin{abstract}
Wharton, B. A., Bassi, U., Gough, G., and Williams, A. (1971). Archives of Disease in Childhood, 46, 356. Clinical value of plasma creatine kinase and uric acid levels during first week of life. Levels of creatine kinase and uric acid in cord blood were variable but similar to those in maternal blood. During the first 24 hours of life there was a rise in the concentration of both substances, particularly of creatine kinase, to reach levels well above those normally found in later childhood. Thereafter there was a steady fall to stable levels around the fifth day. The causes of these obvious changes in concentration are not known.

Uric acid levels during the first 24 hours were higher after a longer labour. Creatine kinase levels were lower, and uric acid levels higher in low birthweight babies. The plasma creatine kinase originated from non-cardiac muscle.

Plasma creatine kinase and uric acid levels may help in the early diagnosis of rare specific disorders such as muscular dystrophy and the Lesch-Nyhan syndrome, but do not help in the diagnosis of other neurological disorders at this time of life, and give no indication of the child's prognosis, despite their occasional help in adult patients. Even with the specific syndromes, however, interpretation must be guarded. It is not known whether the high creatine kinase levels associated with Duchenne muscular dystrophy would be lost in the upper limits of the normal range for the first few days of life or whether they would be higher still. In the Lesch-Nyhan syndrome uric acid levels are well above the normal range defined in this investigation.
\end{abstract}

Disordered function of the central nervous system is common during the first few days of life. If simple biochemical 'tests' for these abnormalities were evolved they would be of considerable clinical value in diagnosis, for the indication of high risk babies, and for the assessment of treatment. They might also enable a more accurate prognosis to be given. It seemed possible that creatine kinase and uric acid might be useful in this context.

It is known that plasma creatine kinase levels may help in the differential diagnosis of a floppy baby (Dubowitz, 1969), and work on cerebrovascular accidents and head injuries in adults has shown that plasma levels of creatine kinase are sometimes raised after brain damage (Acheson et al., 1965; Dubo et al., 1967; Langton et al., 1967). Similarly, uric acid levels may help in determining the nature of choreoathetosis and mental deficiency (Lesch and Nyhan, 1964); levels are sometimes raised in mongolism (Pant, Moser, and Krane, 1968); in adults a raised uric acid level is regarded

\footnotetext{
Received 4 November 1970.

* Present address: Institute of Child Health, and Queen Elizabeth Hospital for Children, London E.2.
}

as a predisposing factor in cerebrovascular accidents (Hansen, 1965; Pearce and Aziz, 1969), and there is some suggestion that raised levels may be found in dyslexia/dysgraphia (Parker, 1967) though this is disputed (Zahálková et al., 1969).

In recent years, investigators, parcicularly from the European continent, have defined the normal range, during the newborn period, of creatine kinase (Natoli et al., 1966; Sitzmann, 1967; Verri, Macagno, and Corazza, 1966) and of uric acid (Christiansson and Josephson, 1960; Castello et al., 1968), but only a few have given clinical data in any detail either with the creatine kinase levels (Rudolph and Gross, 1966; Ballario and Pavesio, 1969) or with uric acid levels (Marks et al., 1968a). In none of these investigations have the biochemical findings been correlated with the subsequent neurological development of the child.

In view of the limited clinical details available, a prospective investigation was planned to restudy the range of plasma creatine kinase and uric acid levels during the first week of life and to correlate these with the clinical state of the child and his subsequent development. The investigation also 
provided an opportunity to study the isoenzyme pattern of plasma creatine kinase in the early days of life.

\section{Methods}

The investigation was in 3 phases.

Phase 1. Venous blood was obtained from 19 mothers shortly after delivery and again at a known time during the first 24 hours after birth. Blood samples were obtained from their babies at the same time (cord blood at birth; capillary blood subsequently).

Phase 2. The normal newborn nursery and the Special Care Baby Unit were visited on Monday, Wednesday, and Friday of each week and heel-prick samples of blood were collected from babies less than 1 week old whose mothers had consented to the investigation. 281 samples were collected from 151 term babies and 47 from 26 low birthweight babies. The birthweight, maturity, mode of delivery, Apgar score at $\mathbf{1 0}$ minutes, and the number of hours in labour were recorded for each birth together with details of the age and clinical state of the child at each collection.

Phase 3. Certain children from Phase 2 were selected for follow up: (a) those whose plasma uric acid or creatine kinase levels were greater than the 90th centile (as determined from this investigation); (b) babies randomly selected from those whose plasma values had remained within the 30 th and 70 th centiles. These babies were seen at the age of 10 months by two of us (B.A.W., U.B.) and a developmental assessment was made according to the methods summarized by Wood (1970) without knowledge of the previous biochemistry.

Children from the special care unit were followed up as part of the normal routine service. It was thought that these repeated assessments would be of more value than a single, albeit 'blind' one as described above. We have therefore consulted the routine follow-up notes made by our colleagues and ourselves concerning these babies.
Chemical methods. Plasma from blood samples was separated within 2 hours of collection and stored at $-20^{\circ} \mathrm{C}$. Duplicate determinations of creatine kinase (Sigma Kit based on the creatine liberation method of Hughes, 1962, but incorporating glutathione instead of cysteine) and uric acid (Boehringer Kit, based on the highly specific uricase method of Praetorius and Poulsen, 1953) were then made within one week of collection. Creatine kinase results are expressed as Sigma units per ml; one Sigma unit of creatine kinase phosphorylates $1 \mathrm{~m} \mu$ mole creatinine per minute at $25^{\circ} \mathrm{C}$ under the conditions of Sigma procedure No. 40 UV (Sigma Technical Bulletin No. 520). The upper limit of normal for this method in adults is 20 Sigma units per $\mathrm{ml}$.

The isoenzymes of creatine kinase were separated by cellulose acetate electrophoresis whenever the total activity was greater than 60 units per $\mathrm{ml}$, using the method of Trainer and Gruenig (1968) with minor modifications.

\section{Results}

Phase 1. Table I shows the plasma levels of creatine kinase and uric acid, in maternal and cord blood on delivery and in the same mothers and babies some hours after birth.

Creatine kinase levels in cord blood were very variable and on average were slightly higher than in maternal blood but not significantly so. After birth, levels in maternal blood remained steady, but in the babies, levels rose rapidly during the first 12 hours and then began to fall.

Uric acid levels were similar in cord and maternal blood but in many instances were much higher than usually found in adult life. In the 24 hours after birth, levels in the maternal blood remained steady, but levels in the babies rose during the first 12 hours and then began to fall.

TABLE I

Plasma Levels of Creatine Kinase and Uric Acid in Maternal and Cord Blood on Delivery and in Wothers and Babies some Hours after Birth

\begin{tabular}{|c|c|c|c|c|c|}
\hline \multirow{3}{*}{$\begin{array}{l}\text { Time } \\
\text { of Blood } \\
\text { Collection }\end{array}$} & \multirow{3}{*}{$\begin{array}{l}\text { No. of } \\
\text { Pairs } \\
\text { Studied }\end{array}$} & \multicolumn{4}{|c|}{ Plasma Levels-mean and range } \\
\hline & & \multicolumn{2}{|c|}{ Creatine Kinase (Sigma units/ml) } & \multicolumn{2}{|c|}{ Uric Acid (mg/100 ml) } \\
\hline & & Mother & Child (cord) & Mother & Child (cord) \\
\hline Birth & 19 & $\begin{array}{c}10 \\
(0-30) \\
\text { Cord minus materna }\end{array}$ & $\begin{array}{c}15^{\star} \\
(0-55) \\
+5(-8,+33)\end{array}$ & $\begin{array}{c}6 \cdot 1 \\
(3 \cdot 3-8 \cdot 2) \\
\text { Cord minus maternal }\end{array}$ & $\begin{array}{c}6 \cdot 2^{\star} \\
(4 \cdot 5-8 \cdot 2) \\
+0 \cdot 1(-0 \cdot 4,+1 \cdot 7)\end{array}$ \\
\hline 2-12 hours post partum & 9 & $\begin{array}{c}15 \\
(5-25)\end{array}$ & $\begin{array}{c}60 t \\
(5-150)\end{array}$ & $\begin{array}{c}6 \cdot 3 \\
(4 \cdot 9-8 \cdot 6)\end{array}$ & $\begin{array}{c}7 \cdot 5 \dagger \\
(6 \cdot 1-9 \cdot 0)\end{array}$ \\
\hline 13-24 hours post partum & 10 & $\begin{array}{c}15 \\
(5-25)\end{array}$ & $\begin{array}{c}25 \\
(5-60)\end{array}$ & $\begin{array}{c}6 \cdot 0 \\
(4 \cdot 5-6 \cdot 5)\end{array}$ & $\begin{array}{c}6 \cdot 1 \\
(4 \cdot 9-7 \cdot 8)\end{array}$ \\
\hline
\end{tabular}

* Not significantly different from maternal blood.

† Significantly greater than in cord blood: creatine kinase $\mathbf{P}<0.02$. uric acid $\mathbf{P}<0.01$. 
TABLE II

Plasma Creatine Kinase Levels in Normal Term Babies during First Week of Life

\begin{tabular}{|c|c|c|c|c|c|c|}
\hline \multirow{3}{*}{$\begin{array}{l}\text { No. of } \\
\text { Babies } \\
\text { Studied }\end{array}$} & \multirow{3}{*}{$\begin{array}{c}\text { Age } \\
\text { at } \\
\text { Blood } \\
\text { Collection } \\
\text { (hr) }\end{array}$} & \multicolumn{5}{|c|}{ Plasma Creatine Kinase (Sigma units/ml) } \\
\hline & & \multirow{2}{*}{ Highest } & \multicolumn{3}{|c|}{ Centiles } & \multirow{2}{*}{ Lowest } \\
\hline & & & 90 & 50 & 10 & \\
\hline $\begin{array}{l}45 \\
45 \\
40 \\
49 \\
49 \\
53\end{array}$ & $\begin{array}{c}1-12 \\
13-24 \\
25-48 \\
49-72 \\
73-120 \\
121-168\end{array}$ & $\begin{array}{r}170 \\
160 \\
70 \\
60 \\
40 \\
25\end{array}$ & $\begin{array}{l}55 \\
75 \\
55 \\
40 \\
30 \\
20\end{array}$ & $\begin{array}{l}30 \\
35 \\
30 \\
20 \\
15 \\
10\end{array}$ & $\begin{array}{r}15 \\
15 \\
10 \\
10 \\
5 \\
5\end{array}$ & $\begin{array}{l}5 \\
5 \\
5 \\
5 \\
5 \\
5\end{array}$ \\
\hline
\end{tabular}

Phase 2. Term babies. Table II shows the creatine kinase results during the first week of life in term babies in the normal newborn nursery. Levels are high during the first $\mathbf{2 4}$ hours, rapidly falling thereafter.

Table III shows the uric acid results during the first week of life. The trend is similar to that observed with creatine kinase.

TABLE III

Plasma Uric Acid Levels in Normal Term Babies during First Week of Life

\begin{tabular}{|c|c|c|c|c|c|c|}
\hline \multirow{3}{*}{$\begin{array}{l}\text { No. of } \\
\text { Babies } \\
\text { Studied }\end{array}$} & \multirow{3}{*}{$\begin{array}{c}\text { Age } \\
\text { at } \\
\text { Blood } \\
\text { Collection } \\
\text { (hr) }\end{array}$} & \multicolumn{5}{|c|}{ Plasma Uric Acid (mg/100 ml) } \\
\hline & & \multirow{2}{*}{ Highest } & \multicolumn{3}{|c|}{ Centiles } & \multirow{2}{*}{ Lowest } \\
\hline & & & 90 & 50 & 10 & \\
\hline $\begin{array}{l}45 \\
45 \\
40 \\
49 \\
49 \\
53\end{array}$ & $\begin{array}{c}1-12 \\
13-24 \\
25-48 \\
49-72 \\
73-120 \\
121-168\end{array}$ & $\begin{array}{c}9 \cdot 8 \\
9 \cdot 8 \\
11 \cdot 9 \star \\
8 \cdot 6 \\
5 \cdot 7 \\
5 \cdot 7\end{array}$ & $\begin{array}{l}8 \cdot 5 \\
8 \cdot 5 \\
8 \cdot 2 \\
6 \cdot 6 \\
4 \cdot 9 \\
4 \cdot 9\end{array}$ & $\begin{array}{l}6 \cdot 5 \\
7 \cdot 0 \\
5 \cdot 3 \\
4 \cdot 1 \\
3 \cdot 3 \\
3 \cdot 3\end{array}$ & $\begin{array}{l}5 \cdot 0 \\
5 \cdot 0 \\
3 \cdot 3 \\
3 \cdot 2 \\
2 \cdot 5 \\
2 \cdot 5\end{array}$ & $\begin{array}{l}3 \cdot 3 \\
1 \cdot 6 \\
2 \cdot 7 \\
2 \cdot 5 \\
2 \cdot 0 \\
2 \cdot 4\end{array}$ \\
\hline
\end{tabular}

$\star$ This child lost $350 \mathrm{~g}$ during the first week of life but no abnormality was found. He developed abnormal neurological signs at 1 month of age; next highest uric acid level in another child was $9.5 \mathrm{mg} / 100 \mathrm{ml}$.

Table IV shows the effect of certain perinatal factors on the levels of the 2 substances in the 90 babies from whom blood was obtained during the first 24 hours. Uric acid levels were higher after a long labour, but no other significant differences were observed.

Low birthweight babies. Fig. 1 compares the creatine kinase results observed in low birthweight babies to the normal range in term children. There was a wide spread of values but they tended to be lower in the low birthweight children, e.g. twothirds of the levels in these small children were below the median for term babies $(P<0 \cdot 05)$.
TABLE IV

Plasma Levels of Creatine Kinase and Uric Acid in First 24 hours of Life Compared to Certain Perinatalos Details of Children Studied

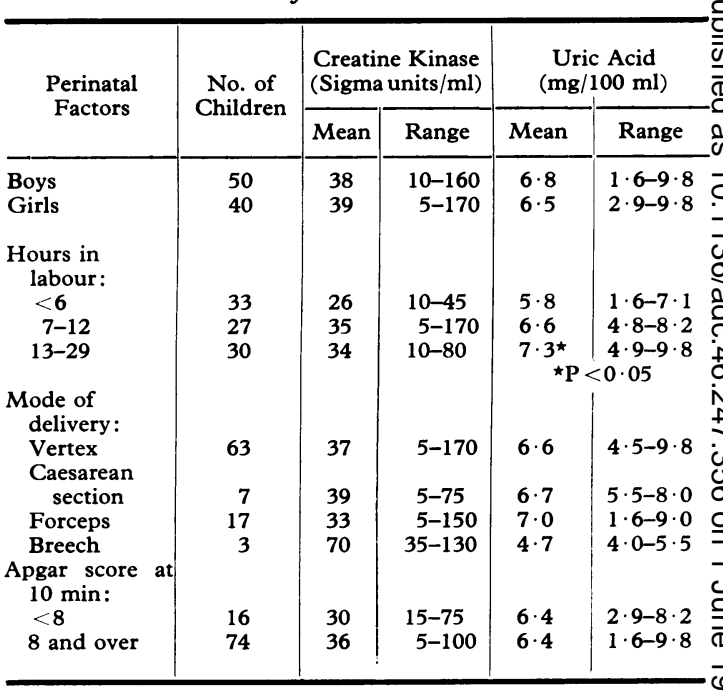

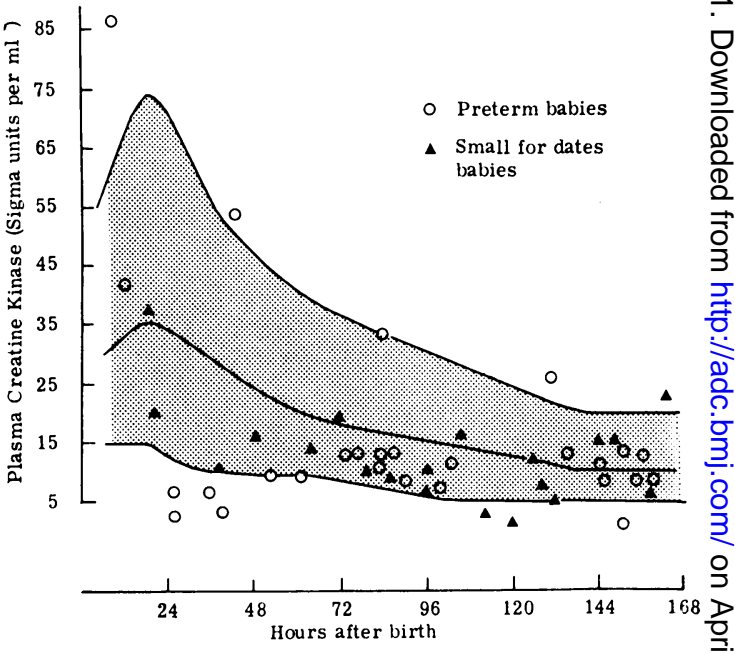

FIG. 1.-Plasma creatine kinase levels in low birthweight $\mathrm{N}$ babies. The shaded area encloses the range (10-90th or centiles) observed in normal term babies.

Levels in preterm babies did not differ from those $\underset{0}{0}$ in small-for-dates babies.

Fig. 2 shows the uric acid levels in low birthweight $\stackrel{\circ}{=}$ babies. The uric acid levels, particularly in the preterm babies, were higher than in term children; e.g. a quarter of the levels found in preterm children $\overrightarrow{0}$ were higher than the 90th centile for normal term $\mathbb{D}$ babies $(P<0 \cdot 05)$. 


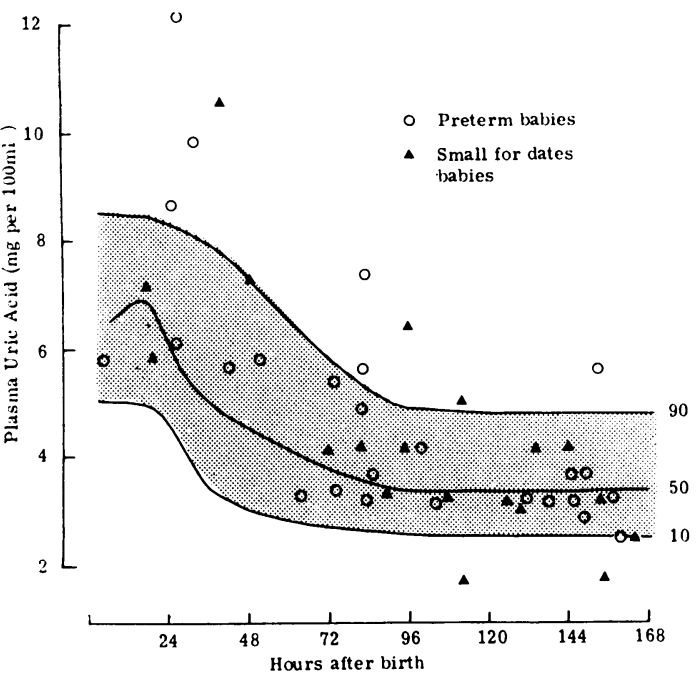

Fig. 2.-Plasma uric acid levels in low birthweight babies. The shaded area encloses the range (10-90th centiles) observed in normal term babies.
Further inspection of the results showed that uric acid results tended to be higher in the smaller and more immature babies and the creatine kinase to be lower in the smaller ones, though these trends were not significant statistically.

Children with clinical abnormalities. Table V show the clinical and biochemical features of those children who were abnormal clinically, either at birth or subsequent follow-up. Of the 13 term babies with clinical abnormalities, $4(31 \%)$ had high (greater than 90th centile) creatine kinase values and $3(23 \%)$ had high uric acid ones. This incidence of high levels was greater than that found in clinically normal babies (14\% of 138 clinically normal term babies had a high creatine kinase level and $10 \%$ of them had a high uric acid level sometime during the first week of life), but the differences are far from statistical significance $(P=0 \cdot 15) .3$ other features in Table V may be noted: (a) Case 13 now appears to be a variant of the Lesch-Nyhan syndrome and had a very high uric acid level 26 hours after birth $(11.9 \mathrm{mg} / 100 \mathrm{ml}$, 90th centile =

TABLE V

Clinical and Biochemical Details of Children Considered to be Neurologically Abnormal or Potentially so Either at Birth or on Follow-up

\begin{tabular}{|c|c|c|c|c|}
\hline \multirow{2}{*}{$\begin{array}{l}\text { Case } \\
\text { No. }\end{array}$} & \multirow{2}{*}{$\begin{array}{c}\text { Clinical State During First Week } \\
\text { of Life }\end{array}$} & \multicolumn{2}{|c|}{$\begin{array}{l}\text { Highest Recorded Plasma Level } \\
\text { (centile) }\end{array}$} & \multirow[t]{2}{*}{ Clinical State at Follow-up } \\
\hline & & Creatine Kinase & Uric Acid & \\
\hline $1-3$ & $\begin{array}{l}\text { (a) Term babies } \\
\text { Babies requiring exchange transfusion; no } \\
\text { signs of kernicterus }\end{array}$ & $50-90$ & $10-50$ & Normal \\
\hline 4 & Anencephaly & $>90$ & $50-90$ & Dead \\
\hline 6 & Hypocalcaemia with irritability & 90 & 10 & Normal \\
\hline 7 & 'Floppy' & $10-50$ & 10 & Normal \\
\hline 8 & Comatose; retinal haemorrhages & 50 & 90 & Arrested hydrocephalus \\
\hline 9 & $\begin{array}{l}\text { Tracheal intubation, cerebral irritation, } \\
\text { fractured humerus bilirubin } 15 \mathrm{mg} / 100 \\
\mathrm{ml}\end{array}$ & $>90$ & 10 & Normal \\
\hline 10 & $\begin{array}{l}\text { Tracheal intubation, forceps for fetal } \\
\text { distress }\end{array}$ & $>90$ & $50-90$ & Normal \\
\hline 11 & $\begin{array}{l}\text { Transposition of great arteries, arhinen- } \\
\text { cephaly }\end{array}$ & $>90$ & $>90$ & Dead \\
\hline 12 & Large cephalhaematomata & $10-50$ & 90 & Normal \\
\hline 13 & Normal & 50 & Highest & $\begin{array}{l}\text { Presented at } 1 \mathrm{mth} \text { with feeding diffi- } \\
\text { culty, abnormal movements and uric } \\
\text { acid of } 8 \cdot 7 \mathrm{mg} / 100 \mathrm{ml} \text {; at } 1 \text { yr: } \\
\text { cranial capacity below } 5 \text { th centile, } \\
\text { development quotient } 50 \text {. }\end{array}$ \\
\hline $\begin{array}{l}14 \\
15 \\
16\end{array}$ & $\begin{array}{l}\text { (b) Low birthweight babies } \\
\text { Tracheal intubation, normal thereafter } \\
\text { Tracheal intubation, normal thereafter } \\
\text { Triplet, precipitate labour, intestinal } \\
\text { obstruction, and perforation }\end{array}$ & $\begin{array}{r}>90 \\
10-50 \\
>90\end{array}$ & $\begin{array}{r}10-50 \\
50-90 \\
>90\end{array}$ & $\begin{array}{l}\text { Normal } \\
\text { Normal } \\
\text { Dead }\end{array}$ \\
\hline $\begin{array}{l}17 \\
18\end{array}$ & $\begin{array}{l}\text { Triplet, precipitate labour } \\
\text { Normal }\end{array}$ & $\begin{array}{l}10-50 \\
10-50\end{array}$ & $\begin{array}{r}>90 \\
50-90\end{array}$ & $\begin{array}{l}\text { Developmental quotient } 50 \text { at } 1 \mathrm{yr} \\
\text { Left hemiplegia noted at } 3 \mathrm{mth}\end{array}$ \\
\hline 19 & $\begin{array}{l}\text { Hypoglycaemia with symptoms; pneu- } \\
\text { monia }\end{array}$ & $>90$ & $50-90$ & Motor delay noted at 4 and $9 \mathrm{mth}$ \\
\hline 20 & Hypoglycaemia without symptoms & $10-50$ & $50-90$ & Normal \\
\hline
\end{tabular}


TABLE VI

Developmental Age at Chronological Age of 10 months of Children who were Clinically Normal at Birth

\begin{tabular}{|c|c|c|c|c|c|c|}
\hline \multirow{2}{*}{ Plasma Level during First Week } & \multicolumn{2}{|c|}{ No. of Children } & \multicolumn{4}{|c|}{ Mean Developmental Age (mth) } \\
\hline & Not Traced & Examined & Motor & Social & $\begin{array}{l}\text { Hearing } \\
\text { and Speech }\end{array}$ & $\begin{array}{c}\text { Eye } \\
\text { and Hand }\end{array}$ \\
\hline $\begin{array}{l}\text { Creatine kinase greater than } 90 \text { th centile on at least } \\
\text { one occasion } \\
\text { Uric acid greater than } 90 \text { th centile on at least one } \\
\text { occasion } \\
\text { Creatine kinase and uric acid greater than 90th } \\
\text { centile on at least one occasion } \\
\text { Randomly selected controls (creatine kinase and } \\
\text { uric acid } 30-70 \text { th centile) }\end{array}$ & $\begin{array}{l}2 \star \\
3 t \\
- \\
3\end{array}$ & $\begin{array}{r}15 \\
7 \\
3 \\
18\end{array}$ & $\begin{array}{l}13 \cdot 8 \\
11 \cdot 3 \\
10 \cdot 3 \\
11 \cdot 6\end{array}$ & $\begin{array}{l}12 \cdot 2 \\
11 \cdot 1 \\
11 \cdot 3 \\
11 \cdot 4\end{array}$ & $\begin{array}{r}10 \cdot 0 \\
9 \cdot 6 \\
9 \cdot 7 \\
9 \cdot 6\end{array}$ & $\begin{array}{l}11 \cdot 4 \\
11 \cdot 1 \\
11 \cdot 7 \\
11 \cdot 0\end{array}$ \\
\hline
\end{tabular}

* One child seen by health visitor at home; development appeared normal.

+ Two children seen by health visitor at home; development appeared normal.

$8.2 \mathrm{mg} / 100 \mathrm{ml}$ ), but this had fallen to $4.9 \mathrm{mg} / 100$ $\mathrm{ml}$ (90th centile) on the 6th day.

(b) Only 2 babies (Cases 11 and 16) had high levels of both creatine kinase and uric acid; both died during the first week of life.

(c) One child (Case 8) with considerable evidence of brain damage at birth on follow up had normal levels of these substances; similarly a child (Case 18) in whom a left hemiplegia was noted at the age of 3 months without any interceding illness also had normal levels of these substances at birth.

Phase 3. Table VI shows the developmental assessment of those children who were clinically normal at birth but had high biochemical values. There was no evidence that a high creatine kinase or uric acid level in a clinically normal newborn child was associated with a poor prognosis. 3 of these children had both creatine kinase and uric acid levels greater than the 90th centile; their development was regarded as normal.

Isoenzymes of creatine kinase. In all instances where isoenzyme separation was performed, the only band obtained moved slightly to the anode side of the origin in the region of $\gamma$ globulin indicating the cause as skeletal muscle. No evidence of an origin from cardiac muscle or the brain was found.

\section{Discussion}

Clinical interpretation. The range of normal values presented may help when considering the diagnosis of muscular dystrophy and the LeschNyhan syndrome. It is not known, however, whether at this age the creatine kinase level of a boy with Duchenne muscular dystrophy would be much higher than our observed range, or whether it would be 'lost' in the upper limits of the normal $\omega$ range. In their discussions of creatine kinase of levels in cord blood Chadd et al. (1966) and Griffiths $ᄋ$ (1968) have favoured the latter possibility, but there seems no $a$ priori reason for discounting the former alternative. Our experience with Case 13 (Table V), however, suggests that uric acid levels in the Lesch-Nyhan syndrome are well above the normal range from the early days of life, though some caution is necessary since the level had fallen to the 90th centile some 5 days later. A child with the Lesch-Nyhan syndrome described by Marks et al. (1968b) had uric acid levels of over $13 \mathrm{mg} / 100 \mathrm{ml}$, on the 3 occasions that blood was collected during the first week of life.

Apart from such specific disorders, however, these substances seem to be of little help in the diagnosis of other neurological abnormalities in the newborn baby despite their occasional help in the adult. Table $\mathrm{V}$ has shown that children with good evidence of intracranial disorder had normal levels of these substances at birth, while Table VI has shown that other children with much higher levels of these substances were clinically normal at birth and on follow up 10 months later. Table VI has also shown that raised levels of both substances during the early days of life does not necessarily indicate a poor prognosis.

Some investigators, however, have ascribed greater clinical significance to the high levels of creatine kinase. Cao et al. (1969) have claimed that creatine kinase levels were high in 3 children with perinatal hypoxia, but in fact only one of their results was outside the range of normal for newborn children as defined by other groups using a similar two enzyme method of assay (data of Verri et al., 1966; Rudolph and Gross, 1966; Sitzmann, 1967; using method of Tanzer and Gilvarg, 1959). 
Rudolph and Gross (1966) have suggested that the high levels may be due to muscle damage sustained during the birth process, especially as levels after breech delivery were much higher than those after caesarean section. This interpretation may be correct, but while Table IV does show higher values in the 3 babies after breech delivery, there is a considerable overlap of values for different modes of delivery. Whatever the exact explanation, our follow-up studies show it would be unwise to attach much clinical importance to these high values.

The clinical significance of the correlation between uric acid levels and length of labour is uncertain, though it is known that maternal levels of plasma uric acid rise during labour (Steenstrup, 1960).

Developmental biology. The trend of creatine kinase results observed in this investigation, i.e. an acute rise after birth followed by a gentle fall is similar to the data of Rudolph and Gross (1966) and to the combined results of the following investigators: Ballario and Pavesio (1969), Sitzmann (1967), and Verri et al. (1966), all of whom used the method of Tanzer and Gilvarg (1959) for assay. The same trend for uric acid has been observed by Castello et al. (1968) and Marks et al. (1968a) who used different chemical methods from the one in this investigation. The rise and fall of these substances therefore is a repeatedly observed phenomenon whatever chemical methods are used. Christiansson and Josephson (1960) observed high uric acid levels during the first week of life but thought these were due only to the high maternal levels during labour; their data did not show the initial rise.

It is difficult to explain the acute rise and slow fall of these substances. Since both behave similarly, the mechanism may be non-specific and may occur with other substances; serum aldolase for example rises to a peak at the third day before slowly falling (Friedman and Lapan, 1958). It is conceivable that cord clamping cuts off a major excretory pathway for those substances leading to an initial rise with a subsequent fall as clearance by the kidneys (or perhaps by other metabolic pathways in the case of creatine kinase) improves. The higher levels of uric acid in preterm babies observed by us and by Marks et al. (1968a) support this hypothesis. On the other hand if it were correct, creatinine should behave similarly. However, Zweymüller, Widdowson, and McCance (1959) found that the serum creatinine in 4 newborn piglets was $1-6 \mathrm{mg} / 100 \mathrm{ml}$ greater than in the sows, and fell to adult levels by 24 hours after birth; but an initial rise was not observed. Similar information in humans has not been found.

The fall in uric acid has been linked to the fall in the leucocyte and red cell count (Castello et al., 1968) and perhaps this mechanism could explain the initial rise also.

We are grateful to Professor G. Dixon and Dr. P. M. Dunn for allowing us to study mothers and babies in their care, to Sister S. Kitts, Miss D. M. Webster, and Sisters E. J. Luffman and R. Russell for their help and co-operation in the collection of specimens, and to Miss $H$. Whittingham for secretarial help.

\section{REFERENCES}

Acheson, J., James, D. C., Hutchinson, E. C., and Westhead, R. (1965). Serum-creatine-kinase levels in cerebral vascular disease. Lancet, 1, 1306.

Ballario, R., and Pavesio, D. (1969). Considerazioni sul significato della creatinfosfochinasi serica nel neonato. Minerva Pediatrica, 21, 253.

Cao, A., de Virgiliis, S., Lippi, C., and Trabalza, N. (1969). Creatine kinase isoenzymes in serum of children with neurological disorders. Clinica Chimica Acta, 23, 475.

Castello, D., Norelli, M. T., Rosmino, G. P., and Ballario, R. (1968). Uricaemia during the paediatric age. I. In healthy individuals. Panminerva Medica, 10, 472.

Chadd, M., Gray, O. P., Saunders, R. A., and Jones, R. T. (1966). Serum aldolase and phosphocreatine kinase in umbilical cord blood. Fournal of Clinical Pathology, 19, 600.

Christiansson, G., and Josephson, B. (1960). The uric acid concentration in serum from children, newborn infants and mothers after delivery. Acta Paediatrica, 49, 633.

Dubo, H., Park, D. C., Pennington, R. J. T., Kalbag, R. M., and Walton, J. N. (1967). Serum-creatine-kinase in cases of stroke, head injury, and meningitis. Lancet, 2, 743.

Dubowitz, V. (1969). Clinics in Developmental Medicine No. 31. The Floppy Infant, p. 86. Spastics International Medical Publications in association with William Heinemann, London.

Friedman, M. M., and Lapan, B. (1958). Serum aldolase in the neonatal period: including a colorimetric determination of aldolase by standardization with dihydroxyacetone. Fournal of Laboratory and Clinical Medicine, 51, 745.

Griffiths, P. D. (1968). The activity of ATP: creatine phosphotransferase (E.C.2.7.3.2) in umbilical cord blood. Clinica Chimica Acta, 20, 465.

Hansen, O. E. (1965). Hyperuricemia in cerebral infarction. Acta Neurologica Scandinavica, 41, Suppl., 13, 357.

Hughes, B. P. (1962). A method for the estimation of serum creatine kinase and its use in comparing creatine kinase and aldolase activity in normal and pathological sera. Clinica Chimica Acta, 7, 597.

Langton, L., Moxon, C. P., Riddoch, D., Westhead, R. A., and Woolf, A. L. (1967). Jugular bulb creatine kinase as an indication of slight transient brain damage. Lancet, 2, 278.

Lesch, M., and Nyhan, W. L. (1964). A familial disorder of uric acid metabolism and central nervous system function. American Fournal of Medicine, 36, 561 .

Marks, J. F., Kay, J., Baum, J., and Curry, L. (1968a). Uric acid levels in full term and low-birth-weight infants. Fournal of Pediatrics, 73, 609.

Marks, J. F., Baum, J., Keele, D. K., Kay, J. L., and MacFarlen, A. (1968b). Lesch-Nyhan syndrome treated from the early neonatal period. Pediatrics, 42, 357.

Natoli, G., Lapi, A. S., Mancini, G., Gerlini, G., and Natoli, V. (1966). Le ultramicroanalisi di laboratorio nella pratica pediatrica. III. Dosaggio spettrofotometrico di alcune attività enzimatiche sieriche e valori normali nelli infanzia. Archivio Italiano di Pediatria e Puericoltura, 24, 373.

Pant, S. S., Moser, H. W., and Krane, S. M. (1968). Hyperuricemia in Down's syndrome. Fournal of Clinical Endocrinology and Metabolism, 28, 472.

Parker, W. S. (1967). Dyslexia-dysgraphia. Lancet, 1, 444. 
Pearce, J., and Aziz, H. (1969). Uric acid and plasma lipids in cerebrovascular disease. I. Prevalence of hyperuricaemia. British Medical fournal, 4, 78.

Praetorius, E., and Poulsen, H. (1953). Enzymatic determination of uric acid with detailed directions Scandinavian fournal of Clinical and Laboratory Investigation, 5, 273.

Rudolph, N., and Gross, R. T. (1966). Creatine phosphokinase activity in serum of newborn infants as an indicator of fetal trauma during birth. Pediatrics, 38, 1039.

Sitzmann, F. C. (1967). Kreatinphosphokinase-Aktivität im Serum bei säuglingen und Kleinkindern. Zeitschrift fur Kinderheilkund, 99, 48.

Steenstrup, O. R. (1960). A note on hyperuricemia during labor. Scandinavian fournal of Clinical and Laboratory Investigation, $12,205$.

Tanzer, M. L., and Gilvarg, C. (1959). Creatine and creatine kinase measurement. Fournal of Biological Chemistry, 234, 3201.
Trainer, T. D., and Gruenig, D. (1968). A rapid method for the analysis of creatine phosphokinase isoenzymes. Clinica Chimica Acta, 21, 151.

Verri, B., Macagno, F., and Corazza, G. (1966). La creatinfosfochinasi (CPK) nelle varie età pediatriche. Minerva Pediatrica, 18, 2256.

Wood, B. S. B. (1970). A Paediatric Vade-Mecum, 7th ed., p. 5. Lloyd-Luke, London.

Zahálková, M., Vrzal, V., Klobouková, E., and Tuma, A. (1969). Dyslexia and serum-uric-acid. Lancet, 2, 651 .

Zweymüller, E., Widdowson, E. M., and McCance, R. A. (1959). The passage of urea and creatinine across the placenta of the pig. Fournal of Embryology and Experimental Morphology, 7, 203.

Correspondence to Dr. B. A. Wharton, Queen Elizabeth Hospital for Children, Hackney Road, London E2 8PS. 